\title{
PROSES NEGOSIASI PEREMPUAN WIRAUSAHA AGRIBISNIS PANGAN BERDASARKAN PENDEKATAN SISTEM AGRIBISNIS DI KOTA BOGOR
}

\author{
Yusalina' Rachmat Pambudy \\ Institut Pertanian Bogor \\ yusalina0115@gmail.com,pambudy_agb@yahoo.com
}

\begin{abstract}
The aims of the study are to describe negotiation process and to find how women entrepreneurs interpret their negotiations. This study was based on interpretive paradigm with phenomenological approach that resulted in qualitative data. The selected subject consisted of 16 women entrepreneurs offood agribusiness in Bogor City. The data were obtained through in-depth interviews, observation and document analysis. The results show that both formal and informal negotiation process which involves people/parties with various interests. The success of negotiation process is affected by negotiation strategies, such as time, location, media communication, and distributive and integrative strategies.
\end{abstract}

Keywords: Food agribusiness, Negotiation Strategy, Phenomenology, Women Entrepreneurs.

\section{PENDAHULUAN}

Perempuan wirausaha adalah salah satu pelaku bisnis yang memiliki peran yang besar dalam pengembangan ekonomi suatu negara. Disadari atau tidak, di lingkungan sekitar kita menunjukkan keberadaan perempuan sebagai wirausaha yang berkembang cukup signifikan untuk meningkatkan kondisi ekonomi keluarganya. Berdasarkan data Survei Angkatan Kerja Nasional (Sakernas) Agustus 2016, jumlah perempuan yang berprofesi sebagai wirausaha/pengusaha adalah 14,3 juta orang (Kompas.com, 17 Juni 2017).

Salah satu kota yang berkembang bisnis yang dikelola oleh perempuan wirausaha adalah Bogor. Adapun bisnis yang digeluti oleh perempuan wirausaha tersebut, salah satunya adalah agribisnis pangan dalam bentuk produk olahan yang dikerjakan di lokasi rumah dan bukan di pabrik.

\begin{abstract}
Produk yang dikembangkan memanfaatkan bahan baku komoditas agribisnis dengan mengeksplorasi sumber daya khas yang dimiliki tiap daerah melalui penciptaan produk kebanggaan lokal. Dalam menjalankan bisnisnya, perempuan wirausaha agribisnis pangan di Bogor mengalami permasalahan pengelolaan sumberdaya, antara lain tenaga kerja, modal, informasi, produksi, teknologi, dan keuangan. Sumberdaya tersebut berada diluar jangkauannya, sehingga perempuan wirausaha dituntut bernegosiasi untuk membangun kesepakatan dengan berbagai pihak tentang hal tersebut. Negosiasi tersebut merupakan suatu proses komunikasi yang dilakukan dengan rekan bisnis, karyawan, pihak pemasok bahan baku, investor untuk menambah modal, pembuat kebijakan, maupun pihak konsumen baik konsumen individu maupun kelompok (perusahaan).
\end{abstract}


Peneliti ini berusaha untuk mengetahui pengalaman negosiasi mereka dan bagaimana proses negosiasi dan hambatan apa yang dihadapi ketika melakukan negosiasi. Selain itu, posisi mereka sebagai seorang perempuan wirausaha dan juga ibu rumahtangga tentunya akan berdampak pula pada bagaimana proses negosiasi yang mereka lakukan dan strategi negosiasinya agar kedua peran tersebut dapat berjalan dengan baik.

Penelitian terdahulu tentang negosiasi telah dilakukan oleh beberapa peneliti. Penelitian tentang negosiasi perempuan wirausaha dilakukan oleh Nandonte dan Liana (2013: 28-45). Penelitian ini bertujuan untuk menganalisis perilaku negosiasi bisnis yang dilakukan oleh perempuan wirausaha yang bergerak di bidang agribisnis di Tanzania. Sampel terdiri dari 131 perempuan wirausaha kecil (UMKM) yang terlibat dalam bisnis pertanian di Pasar Mawenzi yang merupakan pusat penjualan hasil pertanian dari berbagai tempat di Tanzania. Hasil penelitian menunjukkan berdasarkan proses negosiasinya, media komunikasi yang digunakan selama proses negosiasi adalah komunikasi tatap muka dengan alasan dapat secara langsung kontak dengan pembeli dan langsung menegosiasikan harga walaupun dapat dilakukan melalui email atau telepon selular. Hal ini terjadi karena kurang percaya terhadap pembeli (takut ditipu), apalagi kalau pembeli adalah laki-laki.

Penelitian lain yang berkaitan dengan proses pengambilan keputusan yang dilakukan oleh perempuan wirausaha dilakukan oleh Yu (2011: 111). Penelitian ini merupakan hasil survey nasional di Cina yang dilakukan terhadap sampel yang terdiri dari 3012 perusahaan swasta. Hasil penelitian menunjukkan dalam proses pengambilan keputusan dengan shareholder dan board director, tidak ada perbedaan yang signifikan. Hal ini dipengaruhi oleh struktur perusahaan dan gaya kepemimpinan yang berbeda. Akan tetapi, perempuan wirausaha cenderung lebih menyukai kepemimpinan partisipasi dan membangun hubungan, walaupun menyebabkan pengambilan keputusan menjadi lebih lama dan dapat merugikan dirinya sendiri. Selanjutnya, penelitian yang dilakukan oleh Canet-Giner dan Saorin-Iborra (2007: 209) menunjukkan pengaruh perbedaan gender pada pilihan perilaku negosiasi, dan akibatnya pada hasil negosiasi. Penelitian ini menekankan pada negosiasi aliansi/kesepakatan strategis sebagai kerangka kontekstual yang dianalisis. Hasil penelitian menunjukkan bahwa profil jenis kelamin bertindak positif dalam membina perilaku integratif, sementara profil yang lebih mirip dengan stereotip maskulin, cenderung menunjukkan perilaku yang lebih kompetitif. Penelitian tentang proses negosiasi yang lebih kompleks ditunjukkan oleh penelitian Browne (1979: 61). Data diperoleh dengan cara melakukan pengamatan berpartisipasi selama 16 minggu terhadap 24 salesman yang melakukan interaksi dengan salesman lainnya,pengusaha dan pelanggan/konsumen. 


\section{PROSES NEGOSIASI PEREMPUAN WIRAUSAHA AGRIBISNIS PANGAN BERDASARKAN PENDEKATAN SISTEM AGRIBISNIS DI KOTA BOGOR}

Penelitian ini bertujuan untuk memahami proses interaksi dalam tiga level, yaitu: (1) The used car game, berdasarkan gambaran yang spesifik tentang transaksi, (2) Perspektif perantara (Middleman) dengan fokus pada bagaimana proses transaksi berdasarkan pandangan pihak perantara, dan (3) Transaksi dalam format yang umum. Ketiganya berbeda sudut pandang tetapi dengan proses yang sama. Salesman mobil sangat "profesional" dan ahli dibidang jual beli mobil karena merupakan pekerjaannya sehari-hari. Dalam pekerjaan ini, uang adalah salah satu komoditi penting, tetapi membangun kepercayaan jauh lebih penting. Penelitian ini dilakukan secara alamiah, karena dalam pelaksanaannya semua orang tidak mengetahui dalam pengamatan dan bernegosiasi sesuai aturan. Penelitian ini menunjukkan secara detail proses negosiasi yang terjadi pada ketiga level tersebut. Setiap level terdapat model yang menunjukkan proses dari awal transakasi akan dilakukan, sampai hasil akhir yang akan terjadi bila transaksi berjalan dengan baik atau mengalami kegagalan.

Berbeda dengan penelitian sebelumnya, penelitian ini berusaha untuk menjelaskan pengalaman dan pemahaman perempuan wirausaha agribisnis pangan yang bersifat personal terhadap proses negosiasi yang dilakukannya. Hal ini menjadikan suatu hal yang menarik karena setiap perempuan wirausaha menghadapi berbagai lawan negosiasi yang memiliki sifat dan karakter yang berbeda.

\section{METODE PENELITIAN}

\section{Subyek Penelitian}

Subyek penelitian terdiri dari 16 orang perempuan wirausaha agribisnis pangan dengan kriteria:(1) pemilik/pimpinan usaha, (2) domisili di Bogor, dan (3) menjalankan bisnis pengolahan pangan dan usaha rumah makan/katering (retail) dengan bahan baku hasil pertanian, perikanan dan peternakan. Informasi tentang subyek penelitian berasal informasi yang diperoleh dari Ikatan Pengusaha Wanita (IWAPI) Cabang Bogor, dan beberapa komunitas bisnis di Bogor. Tabel 1 menunjukkan data perempuan wirausaha agribisnis pangan di Bogor yang menjadi subyek penelitian.

Tabel 1. Data Informan berdasarkan Karakteristik Individu

\begin{tabular}{|l|c|c|c|c|r|}
\hline No & $\begin{array}{c}\text { Nama } \\
\text { (Inisial) }\end{array}$ & $\begin{array}{c}\text { Usia } \\
\text { (Tahun) }\end{array}$ & Pendidikan & Sifat bisnis & $\begin{array}{c}\text { Omzet } \\
(\text { Bulan })\end{array}$ \\
\hline 1 & GS & 25 & S1 & Utama & \\
\hline 2 & AL & 29 & S1 & Utama & 8.000 .000 \\
\hline 3 & NS & 35 & SLTA & Utama & 5.000 .000 \\
\hline 4 & AR & 38 & S1 & Utama & 30.000 .000 \\
\hline 5 & GD & 38 & S1 & Utama & 10.000 .000 \\
\hline 6 & NY & 38 & S1 & Utama & 5.000 .000 \\
\hline 7 & RM & 43 & S1 & Utama & 10.000 .000 \\
\hline 8 & RS & 43 & D3 & Sampingan & 20.000 .000 \\
\hline 9 & SA & 48 & S1 & Utama & 18.000 .000 \\
\hline 10 & FC & 50 & S1 & Utama & 40.000 .000 \\
\hline 11 & KD & 52 & SLTA & Utama & 20.000 .000 \\
\hline 12 & AS & 53 & S1 & Utama & 100.000 .000 \\
\hline 13 & EH & 54 & Tidak Tamat & Sampingan & 2.000 .000 \\
& & & SMEA & & \\
\hline 14 & JMR & 59 & SLTA & Utama & 25.000 .000 \\
\hline 15 & TYS & 60 & SD & Utama & 150.000 .000 \\
\hline 16 & KC & 64 & S3 & Sampingan & 40.000 .000 \\
\hline & & & & & \\
\hline
\end{tabular}




\section{Teknik Pengumpulan Data}

Penelitian ini menggunakan teknik pengumpulan data yang dilakukan terdiri dari (1) wawancara mendalam (in-depth interview) untuk menggali pengalaman negosiasi yang dilakukan oleh perempuan wirausaha, observasi dengan mengikuti perempuan wirausaha dalam menjalankan aktivitasnya sebagai seorang wirausaha, dan (3) analisis dokumen dari berbagai media cetak atau media elektronik yang memuat tentang pengembangan bisnis secara umum ataupun khusus yang berkaitan dengan pengembangan bisnis perempuan wirausaha dalam berbagai aspek.

Penelitian dilakukan pada bulan Desember - Juli 2016. Lamanya proses penelitian karena proses wawancara dilakukan dalam berbagai situasi, bahkan saat sedang melakukan proses produksi ataupun melayani pelanggan. Dengan demikian, tidak bisa langsung wawancara tetapi melakukan proses pengamatan karena pada saat tersebut biasanya terjadi tawar-menawar dengan konsumen Di lain waktu, wawancara dilakukan sambil mengikuti informan yang melakukan negosiasi dengan pihak hotel. Dalam kesempatan lain, pengamatan dilakukan pada saat informan ke pasar untuk membeli bahan baku.

\section{TeknikAnalisis Data}

Proses analisis data menggunakan teknik analisis fenomenologis (Creswell : 1998: 147-148). Tahapan tersebut dimulai dengan menggambarkan secara lengkap pengalaman tentang fenomena yang diamati berdasarkan hasil lapangan dan berusaha untuk menemukan pernyataan berdasarkan hasil wawancara, merinci pertanyaan-pertanyaan yang signifikan (horisonalisasi data), dan memperlakukan setiap pernyataan secara seimbang, serta menyusun rincian tersebut agar tidak tumpang-tindih. Selanjutnya, pernyataan tersebut dikelompokkan ke dalam unit-unit bermakna (meaning unit) dan merinci unit-unit tersebut dan menuliskan penjelasan teks (textural description) tentang pengalamannya, termasuk memberikan contoh-contoh untuk memperkuat pernyataan tersebut.

Selanjutnya, mengungkapkan pengalaman peneliti sendiri tentang proses negfsoasisi dan menggunakan variasi imajinatif atau deskripsi struktural, mencari keseluruhan makna yang memungkinkan melalui perspektif yang berbeda, selain itu mempertimbangkan kerangka rujukan tentang fenomena, dan mengkonstruksi bagaimana gejala tersebut terjadi. Hasilnya adalah konstruksi gambaran menyeluruh tentang makna dan esensi dari pengalaman perempuan wirausaha agribsisnis, dan merupakan proses awal peneliti mengungkapkan pengalamannya, dilanjutkan dengan berbagai pertimbangan peneliti menuliskan deskripsi gabungannya.

\section{Teknik Keabsahan Data}

Keabsahan data atau validitas data sebuah usaha untuk menilai ketepatan atau 
keakuratan data penelitian yang digambarkan oleh peneliti. (Cresswel, 2013:249). Adapun aktivitas rinci memeriksa keabsahan data penelitian sesuai dengan pernyataan Moleong (2000: 175), yaitu (1) melakukan perpanjangan waktu penelitian untuk membangun kedekatan dan mendapatkan informasi yang lebih mendalam, (2) melakukan pengamatan terusmenerus terhadap aktivitas perempuan wirausaha sebagai upaya memahami dan mendalami fenomena sosial yang diteliti sebagaimana adanya, dan (3) membuat laporan penelitian yang rinci untuk mengungkapkan makna dan pengalaman subyek.

\section{PEMBAHASAN}

Negosiasi merupakan proses yang kompleks, bahkan Nieuwmeijer (1998: 116) menyatakan " ... not only is negotiation a process, but it also consists of many processes such as communication, influence, coalition forming, problem solving, power building, agenda setting, and debating." Proses negosiasi menunjukkan serangkaian aksi yang diikuti dengan tujuan yang spesifik. Hal ini dilakukan oleh seluruh informan untuk mencapai keberhasilan negosiasi tersebut, agar terjalan hubungan jangka panjang antara informan dan lawan negosiasinya.

Bisnis yang dijalankan oleh para informan dalam konteks sistem agribisnis termasuk pada agribisnis hilir (down stream agribusiness), terutama yang berkaitan dengan produk pengolahan pangan.
Pelaku negosiasi yang berhubungan dengan para informan berdasarkan sistem agribisnis, menunjukkan adanya keterkaitan ke belakang/backward linkage dan ke depan/forward linkage. Keterkaitan ke depan menggambarkan negosiasi dengan pemasok bahan baku/supplier. Selain itu, terdapat sub sistem penunjang yang berada diluar sistem tetapi sangat membantu sistem agar berjalan dengan baik.

Negosiasi yang dilakukan oleh informan untuk mendapatkan bahan baku umumnya dilakukan dengan toko/koperasi dan pedagang pasar yang memasok bahan baku utama untuk produk yang dihasilkan oleh informan.

Kentang adalah bahan baku utama yang diperlukan oleh $\mathrm{KD}$, sedangkan bisnis rumah makan dan katering yang dikelola oleh TYS, DG, AS, dan RS membutuhkan bahan baku ikan, daging ayam, daging sapi, dan sayuran. Adapun pembelian bahan baku dari toko/koperasi biasanya untuk produk yang tahan lama, misalnya beras, gula, tepung, dan minyak goreng. Selain itu, SG melakukan negosiasi dengan peternak yang memasok ayam potong atau petani yang memasok sayuran.

Negosiasi tidak hanya dilakukan untuk mendapatkan bahan baku saja, tetapi juga bagaimana para informan berusaha menunjukkan eksistensi bisnis yang dijalankannya. Keterkaitan ke depan (forward linkage) menggambarkan negosiasi ke berbagai pihak untuk penawaran produk dan mendapatkan/melanjutkan kerjasama 
penjualan atau menjual produk langsung ke pelanggan.

Informan menghasilkan produk yang ditawarkan kepada pedagang perantara dan konsumen akhir. Negosiasi penawaran produk dilakukan ke berbagai pihak untuk mendapatkan kerjasama. Dengan demikian, tidak dapat dihindari terjadinya negosiasi dengan toko kue/toko oleh-oleh, distributor dan reseller. Adapun konsumen akhir adalah pembeli produk yang dihasilkan oleh informan. Produk yang dijual informan umumnya telah ditetapkan harganya, biasanya negosiasi terjadi dalam pembelian dengan jumlah tertentu. KD menjual aneka produk balado dengan ukuran dan harga yang telah ditentukan. Namun, dalam kondisi tertentu ketika ada pesanan dari katering yang membutuhkan dalam ukuran khusus, maka negosiasi sangat diperlukan karena akan ada penyesuaian dalam kemasan dan tentunya akan berpengaruh pula terhadap harga produk.

Keberhasilan bisnis yang dilakukan oleh informan tidak terlepas juga dengan adanya kerjasama dengan berbagai pihak yang mendukung bisnis tersebut. Berdasarkan pengamatan, menunjukkan bahwa informan melakukan negosiasi dengan berbagai pihak yang bertujuan untuk menjalin kerjasama bisnis atau melakukan kemitraan dalam menjalankan bisnis. NY dan RS memiliki mitra bisnis pemilik waralaba. Kerjasama dilakukan dalam bentuk membeli lisensi beserta atributnya dari pihak franchisor (pemilik waralaba) seperti peralatan, proses produksi, resep campuran proses produksinya, pengendalian mutu, pengawasan mutu bahan baku, maupun barang jadinya, serta bentuk pelayannya. Hal yang berbeda dilakukan oleh GS yang bertindak sebagai pewaralaba yang memberikan kesempatan kepada siapapun untuk menjadi mitra bisnisnya. GD selain sharing biaya bisnis, mitra bisnisnya membantu juga dalam melakukan proses produksi.

Berbeda dengan ketiganya, FC mempunyai mitra bisnis dalam bentuk sharing modal dengan kakaknya, tetapi kesepakatannya adalah hanya FC yang mengelola bisnisnya. Hal ini dilakukan setelah bisnis dijalankan dan menunjukkan perkembangan yang menggembirakan. Kondisi tersebut yang menyebabkan FC membutuhkan dana untuk menjadikan bisnis ini menjadi lebih besar.

Selain kemitraan, informan melakukan negosiasi dengan pihak investor, baik lembaga atau perorangan untuk mendapatkan bantuan modal. Berdasarkan hasil wawancara menunjukkan, informan umumnya mendapatkan modal awal dari uangnya sendiri atau bantuan keluarga. Akan tetapi, terdapat tiga orang informan, yaitu $\mathrm{EH}, \mathrm{KD}$ dan AS yang mendapatkan modal dari investor. Namun, modal tersebut diperoleh setelah bisnis berjalan. Hal ini dilakukan karena adanya kebutuhan untuk meningkatkan kapasitas produksi ataupun untuk membeli peralatan yang dibutuhkan agar bisnis berjalan lebih efisien. $\mathrm{KD}$ adalah informan yang mendapatkan kredit yang digunakan untuk membeli peralatan mesin pemotong kentang. 
Faktor pendukung lain yang sangat erat kaitannya dengan keberhasilan informan dalam menjalankan bisnis adalah keberadaan $\mathrm{kel}$ o m pok/kom unitas bisnis. Kelompok/komunitas bisnis adalah kumpulan wirausaha yang bergabung untuk mendapatkan manfaat melalui pertukaran informasi, pengembangan teknologi produksi ataupun membina kerjasama untuk mempermudah manajemen kerja, dan untuk membangun jaringan pertemanan. Berdasarkan hasil penelitian, umumnya informan tergabung satu kelompok/komunitas bisnis. Hanya empat informan yang tidak bergabung dengan kelompok bisnis tersebut, yaitu TYS, NY, KC dan RS. Alasan TYS dan NY karena tidak ada waktu dan harus fokus mengembangkan bisnis. Adapun alasan KC dan RS karena keduanya sehari-hari bekerja secara formal.

Proses negosiasi dengan lawan negosiasi yang berkaitan dengan backward dan forward linkage dalam konteks bisnis termasuk proses negosiasi dengan pihak eksternal perusahaan. Adapun, prosesd negosiasi yang tidak termasuk ke dalam kategori tersebut merupakan proses negosiasi dengan pihak internal, yaitu dengan karyawan dan keluarga. Proses negosiasi internal ini sangat penting dalam menjalankan bisnis, karena karyawan berkepentingan membantu para informan dalam proses produksi. Proses negosiasi dengan karyawan dimulai sejak mereka direkrut untuk bekerja, dengan menyampaikan hal-hal yang berkaitan dengan hak dan kewajiban mereka, serta peraturan yang terkait dengan proses kerja di perusahaannya. Selain itu, dalam kondisi tertentu negosiasi juga termasuk menyelesaikan berbagai permasalahan yang dihadapai oleh karyawan supaya tidak mengganggu kerjanya.

Berdasarkan penjelasan tersebut, bisnis yang dilakukan oleh informan melibatkan karyawan yang bekerja di bagian produksi maupun membantu secara administrasi. Bagi TYS, AS, GD, dan RS yang berbisnis katering, keberadaan karyawan khususnya dibagian produksi sangat menentukan keberlangsungan bisnisnya. Karyawan TYS terdiri dari saudara dan tetangga di kampung, sedangkan karyawan AS berasal dari ibu rumahtangga sekitar perumahan yang bekerja secara tetap atau hanya bekerja kalau ada pesanan yang cukup banyak.

Dengan demikian, terdapat dua macam karyawan yaitu karyawan tetap dan karyawan "cabutan". Konsekuansi dari keduanya adalah dalam hal hak dan kewajiban karyawan terhadap usaha yang dijalankan oleh TYS, AS, GD dan RS. Tugas TYS, AS, GD dan RS melakukan negosiasi dengan karyawan terkait hal tersebut agar tidak menimbulkan permasalahan.

Selain itu, negosiasi dilakukan untuk menyelesaikan berbagai permasalahan yang dialami oleh karyawan. Pada kenyataannya, karyawan adalah manusia biasa yang memiliki permasalahan baik berkaitan dengan dirinya sendiri maupun dengan lingkungan sekitarnya. Karyawan ibu rumahtangga menghadapi permasalahan rumahtangga, dan seringkali dibawa ketika bekerja. Hal ini tidak hanya mempengaruhi dirinya sendiri, misalnya tidak 
ada semangat kerja atau bekerja tidak konsentrasi, tetapi secara tidak langsung berpengaruh pula pada karyawan yang lainnya. Pada akhirnya, tidak bisa dihindari adanya konflik antar karyawan yang merasa dirugikan dengan kondisi rekannya tersebut.

Negosiasi diperlukan untuk menyelesaikan permasalahan tersebut, sehingga tidak akan mengganggu proses produksi. Cara yang dilakukan dengan menghadirkan kedua belah pihak untuk membicarakan masalah tersebut. Ketanggapan TYS dan FC ketika menghadapi masalah karyawannya, sangat membantu untuk mengembalikan suasana kerja menjadi lebih baik.

Di pihak lain, keberadaan keluarga menjadi "kekuatan" bagi para informan dalam menjalankan bisnisnya. Negosiasi dengan mereka tidak hanya berkaitan dengan bagaimana mengurus rumahtangga, tetapi juga bagaimana menjalankan bisnis tanpa mengganggu urusan keluarga tersebut.

Proses negosiasi dengan keluarga dimulai sejak para informan menyampaikan keinginannya untuk menjadi seorang wirausaha, mengingat secara umum para informan adalah seorang istri atau ibu rumahtangga biasa yang menjalankan kegiatan sehari-hari mengurus suami dan anak-anaknya. Akan tetapi, perjalanan kehidupan membawa informan pada satu keyakinan untuk menjadikan bisnis sebagai cara untuk tidak tergantung pada penghasilan suami.
Negosiasi dengan keluarga diperlukan untuk meyakinkan akan kemampuannya untuk membagi waktu antara keluarga dan menjalankan bisnis.

Informan adalah perempuan wirausaha yang memiliki peran ganda sebagai istri, ibu atau anak. Peran sebagai istri dan ibu memberikan implikasi pada upayanya untuk tetap mempertahankan keutuhan keluarga tanpa kehilangan kesempatan untuk menjadi seorang wirausaha yang mandiri. Informan yang memiliki peran sebagai seorang anak pun tetap mengedepankan harapan orangtua tentang apa yang menjadi cita-cita mereka, misalnya tetap menyelesaikan kuliah (GS) atau tetap bekerja (NS).

Dengan demikian, proses negosiasi yang terjadi dalam ruang lingkup keluarga melibatkan suami dan istri, anak dan orangtua, serta ibu dan anak (SA). Negosiasi suami dan istri berkaitan dengan "keiklasan" suami untuk mengizinkan istrinya melakukan bisnis di rumah dengan konsekuensi, perhatian istri terbagi antara suami, anak, dan bisnis yang dijalankannya (RM, TYS, AL, AR, GD, KD, FC, JMR, KC, RS dan EH).

Negosiasi anak dan orangtua berkaitan dengan pilihan menjadi wirausaha (GS dan NS), sedangkan negosiasi antara ibu dan anak dilakukan SA setelah menetapkan diri untuk berbisnis pasca suami meninggal, karena anak-anak masih kecil dan membutuhkan perhatian maka pilihan menjadi wirausaha adalah yang terbaik karena dilakukan di rumah dan tetap dapat menjaga anak-anak. 
Berdasarkan, penjelasan tersebut dapat dikatakan bahwa Informan dalam menjalankan bisnisnya dipengaruhi oleh lingkungan keluarganya. Pada awal mendirikan bisnis, negosiasi dilakukan dengan suami, orangtua bahkan anak untuk mendapatkan persetujuan. Selanjutnya, pada saat bisnis telah berjalan, keputusan bisnis yang diambil oleh informan setelah melakukan negosiasi dengan suami. Dengan demikian, peran keluarga sangat kuat dalam menjalankan bisnis tersebut.

Secara umum, seluruh proses negosiasi yang dilakukan oleh informan terjadi dalam konteks formal maupun konteks informal. Negosiasi yang dilakukan secara formal, umumnya dilakukan dengan agenda yang yang telah disepakati oleh informan dengan lawan negosiasinya. Formalitas ditunjukkan dengan adanya upaya awal dari informan untuk mengajukan proposal, melakukan perjanjian untuk pertemuan, dan melakukan negosiasi, walaupun sebelumnya telah terjalin kerjasama bisnis Hasil akhir dari proses negosiasi formal dalam bentuk kontrak kerja yang mengikat kedua belah pihak. Negosiasi dalam konteks formal ini dialami oleh 10 orang informan, yaitu RS, GD, AS, TYS, EH, AS, NS, JMR, RS, dan KD.

Berdasarkan hasil wawancara dan pengamatan menunjukkan bahwa kegiatan negosiasi formal yang dilakukan oleh informan terdiri dari tiga tahapan yang saling berkaitan, yaitu : (1) pra negosiasi, yaitu pertama menentukan tujuan untuk membuat kesepakatan agar bisa mendapatkan modal, bahan baku, menjual produk dan tujuan lainnya. Hal ini ditegaskan oleh Nieuwmeijer (1998: 130) :

"In a negotiating situation, where the results often involve vast amounts of money, relations, between nations, or human lives, it is of cardinal importance that goals are set."

Kedua menentukan dan mencari informasi tentang lawan negosiasi Hal ini dilakukan untuk mengetahui siapa dan bagaimana karakter lawan negosiasinya sehingga akan memudahkan dalam menentukan strategi untuk menghadapinya. Informasi tersebut diperoleh dari berbagai sumber, antara lain bertanya ke rekan bisnis, ke pegawai toko yang menjadi sasaran negosiasi atau dari Dinas UMKM atau Indag, dan ketiga menyiapkan penawaran dan contoh produk, serta penawaran dalam bentuk proposal; pelaksanaan negosiasi terdiri dari kegiatan membuat janji, menemui klien dan menentukan hasil negosiasi, dan (3) pasca negosiasi yaitu menentukan tindak lanjut setelah membuat kesepakatan dan selanjutnya dituangkan dalam bentuk kontrak kerja.

Adapun, negosiasi informal biasanya dilakukan pada awal membangun hubungan dengan pedagang di pasar dan toko kue/oleholeh atau bahkan setelah terbangun kedekatan dengan klien. Selain itu, hal ini dilakukan pula oleh konsumen yang langsung datang tanpa konfirmasi ke toko/rumah makan untuk 
memesan atau membeli langsung produk yang disediakan (terutama untuk bisnis katering). Informan melakukan negosiasi informal untuk mendapatkan produk (bahan baku) atau menjual produk yang dimilikinya ke pihak lawan negosiasi. Negosiasi informal dilakukan juga terhadap reseller.

\section{Strategi Negosiasi}

Proses negosiasi yang dilakukan oleh informan tentunya tidak terlepas dari strategi negosiasi yang dijalankan agar negosiasi tersebut mendapatkan hasil sesuai dengan tujuan yang telah ditetapkan. Adapun strategi tersebut terdiri dari :

\section{(1) Strategi Penetapan Waktu}

Waktu menjadi permasalahan yang penting bagi perempuan wirausaha. Dalam kesehariannya, waktu yang dimanfaatkan oleh informan terbagi menjadi waktu untuk bisnis dan keluarga. Informan berupaya agar waktu untuk berbisnis tidak mengurangi waktunya berkumpul dengan keluarga. Negosiasi yang dilakukan untuk aktivitas bisnis sangat diperhatikan oleh informan. Strategi waktu ini dilakukan oleh lima orang informan, yaitu RM, AR, KC, GS, dan GD.

Strategi waktu juga berkaitan dengan durasi (lama) atau berapa banyak waktu yang dibutuhkan untuk melakukan negosiasi tersebut. Selain itu, frekuansi negosiasi yang ditetapkan untuk menyelesaikan satu negosiasi sampai berhasil atau bahkan tidak berhasil. Menurut DG, durasi atau frekuansi negosiasi yang dilakukan tergantung seberapa penting dan banyaknya waktu yang ingin diinvestasikan untuk membangun hubungan dengan lawan negosiasi. Dengan demikian, apakah mau menyelesaikan negosiasi itu cukup dengan satu kali pertemuan atau mengatur serangkaian pertemuan. Hal ini sangat tergantung pada materi negosiasi.

\section{(2) Strategi Penentuan Lokasi}

Secara umum, negosiasi yang dilakukan oleh informan berlangsung secara tatap muka, sehingga penentuan lokasi harus menjadi pertimbangan agar kedua pihak merasa nyaman dan tidak terintimidasi. Terdapat empat informan yang menerapkan strategi lokasi dalam melakukan negosiasi, yaitu GD, AS, KD, SA dan EH.

Kesan positif menjadi pertimbangan GD, AS dan KD dalam melakukan negosiasi, karena itu lokasi negosiasi menjadi pertimbangan utama sebelum melakukan negosiasi. Hal ini dilakukan dengan memperhatikan tanggapan apa yang diharapkan dari klien. Apabila untuk suasana negosiasi informal maka bisa dilakukan sambil minum kopi atau makan siang. Akan tetapi, bila mengharapkan tangggapan serius maka lokasi negosiasi dilakukan di tempat yang netral yaitu di kantornya atau di kantor klien. Akan tetapi, EH menganggap lokasi tempat usaha sendiri adalah tempat yang paling tepat untuk melakukan negosiasi karena walaupun di rumah sendiri tetapi $\mathrm{EH}$ menyediakan ruang khusus untuk menerima tamu yang merangkap sebagai 
etalase toko yang memajang berbagai produk yang dihasilkannya.

\section{(3) Strategi Penggunaan Media Komunikasi}

Berdasarkan hasil penelitian menunjukkan bahwa informan memanfaatkan berbagai media komunikasi untuk melakukan negosiasi. Negosiasi langsung berhadapan dengan klien atau komunikasi antarpersona menjadi media komunikasi yang paling sering digunakan oleh informan. Selain negosiasi secara langsung, beberapa informan yaitu AR, RM, KC, NY, KD, SA, FC, JMR dan NS menggunakan jasa reseller untuk pemasaran produknya. Proses negosiasi dengan reseller dilakukan dengan memanfaatkan media sosial.

\section{(4) Strategi Tawar-menawar}

Pada saat negosiasi berlangsung, informan akan melakukan penawaran dan tentunya pihak klien akan menawar sesuai dengan kepentingannya. Strategi tawarmenawar yang dilakukan terdiri dari strategi distributif dan strategi integratif. Terdapat Sembilan informan yang menerapkan strategi tawar-menawar distributif, yaitu RM, TYS, AL, AS, NY, FC, JMR, SA, dan EH.

Adapun, tujuh orang informan yaitu AR, GD, GS, KD, NY, KC dan RS, menerapkan strategi integratif. Informan melakukan strategi distributif ketika menghadapi situasi zero sum, artinya perolehan apapun yang didapatkan adalah dengan mengorbankan pihak lain atau sebaliknya. Hal ini dilakukan oleh FC dan TYS ketika menghadapi karyawanannya.
Selanjutnya, informan melakukan strategi integratif untuk mencari penyelesaian yang menguntungkan kedua belah pihak. Strategi ini mengedapkan hubungan jangka panjang. Strategi ini diharapkan akan menghasilkan kepuasan bagi kedua belah pihak karena keduanya berusaha sebaik mungkin untuk memastikan semua pihak mengakhiri negosiasi dengan membawa paling tidak sebagian dari apa yang telah direncanakan sebelum negosiasi. Solusi yang dihasilkan dari negosiasi seperti ini biasanya memiliki kualitas yang lebih baik dan akan berlaku untuk waktu yang lama. Strategi ini dilakukan dengan membangun kepercayaan dan keterbukaan, menyimak aktif, dan pengkajian alternatif secara bersama-sama. Perilaku yang dibangun adalah menciptakan cara yang terbaik untuk memenuhi kebutuhan semua pihak. Dalam praktiknya, para informan memanfaatkan berbagai strategi dalam melakukan negosiasi. Jadi, tidak hanya menerapkan satu strategi saja tetapi memadukan strategi tersebut dengan menyesuaikan pada negosiasi apa yang akan dilakukan dan siapa sasaran negosiasnya.

Penjelasan tentang proses negosiasi yang dilakukan oleh informan berdasarkan pendekatan sistem agribisnis dapat dijelaskan dalam Gambar 1. 


\section{PROSES NEGOSIASI PEREMPUAN WIRAUSAHA AGRIBISNIS PANGAN BERDASARKAN PENDEKATAN SISTEM AGRIBISNIS DI KOTA BOGOR}

Gambar 1. Model Proses Negosiasi Perempuan Wirausaha Agribisnis Pangan di Bogor berdasarkan Pendekatan Sistem Agribisnis.

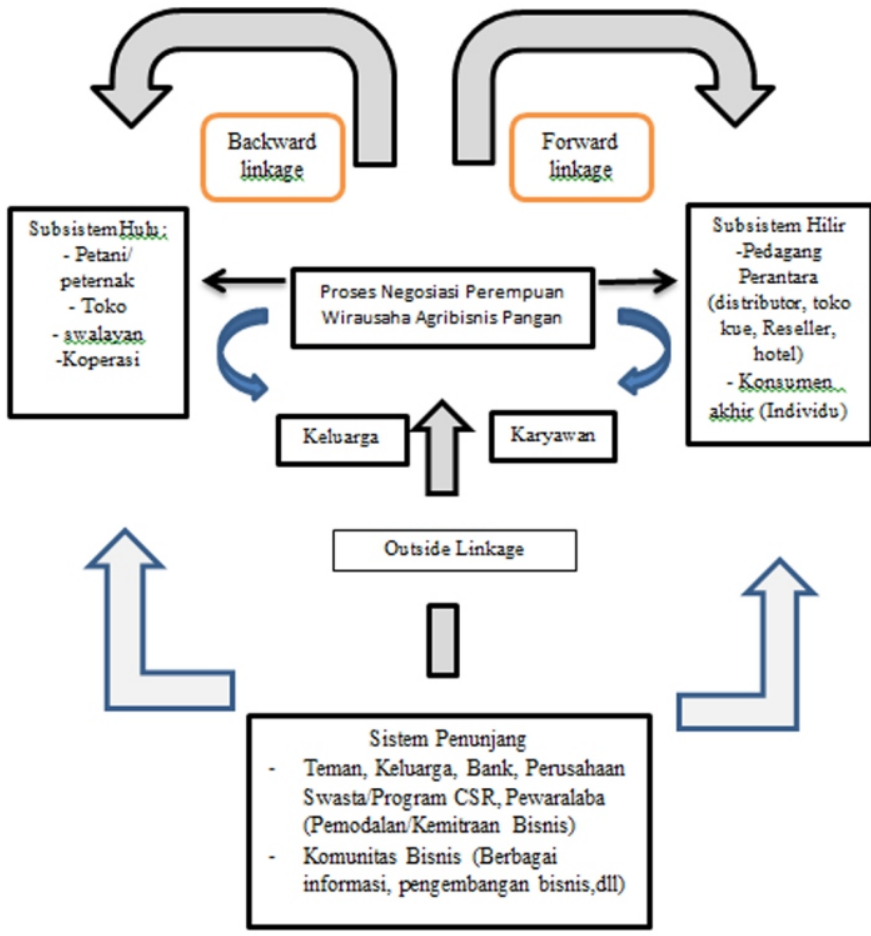

\section{PEMBAHASAN}

Proses negosiasi yang dialami oleh para informan umumnya adalah proses komunikasi antarpribadi yang melibatkan dua pihak, yaitu informan dan lawan negosiasi yang terdiri dari pihak internal maupun eksternal. Komunikasi antarpribadi secara tatap muka sangat penting untuk mendapatkan kesamaan makna terhadap isu yang dibicarakan dalam negosiasi.

Hal ini sejalan dengan hasil penelitian Nandonte dan Liana (2013: 43) yang menunjukkan bahwa perempuan wirausaha melakukan negosiasi secara tatap muka, dengan alasan dapat secara langsung kontak dengan pembeli dan dapat langsung menegosiasikan tentang harga walaupun bisa dilakukan melalui email atau telpon seluler. Dengan demikian, komunikasi tatap muka lebih efisian dan efektif dalam kegiatan negosiasi.

Secara umum, komunikasi antarpribadi dapat diartikan sebagai "the process of message transaction between people (usually two) who work toward creating and sustaining shared meaning." (West dan Turner, 2006:6). Interaksi yang terjadi dalam proses komunikasi antarpribadi berlangsung secara simultan (simultaneous interaction) dengan orang lain dan saling mempengaruhi (mutual influence).

Komunikasi antarpribadi sangat berperan dalam proses negosiasi, karena memiliki dua fungsi utama, yaitu fungsi sosial dan fungsi pengambil keputusan (Liliweri, 1991: 13). Fungsi sosial dikaitkan dengan kemampuan komunikasi antarpribadi untuk mengembangkan hubungan timbal balik, karena pelaku negosiasi akan saling tukar informasi dan berusaha untuk memperoleh kesamaan dan kesetaraan sehingga konsensus akan mudah diambil. Di sisi lain, fungsi pengambil keputusan menjadi hal yang penting dalam proses negosiasi karena informan akan berbagi informasi dan kemudian harus memutuskan kesepakatan yang penting bagi kedua belah pihak. Dengan demikian, dapat dikatakan bahwa, "negotiation is a highly interdependent process, in which decisions of the negotiating parties are interlinked through a variety of interaction between parties" 
(Koeszegi dan Vetschera dalam Kilgour dan Eden, 2010:121).

Berdasarkan proses negosiasi yang dilakukan para informan, menggambarkan bahwa negosiasi yang dilakukan terhadap pihak eksternal terdiri dari: (1) negosiasi untuk memperoleh bahan baku, (2) negosiasi untuk penawaran produk, (3) negosiasi penjualan produk, dan (4) negosiasi kerjasama bisnis/kemitraan. Adapun, negosiasi dengan pihak internal adalah negosiasi yang dilakukan oleh informan untuk membangun kerjasama dan hubungan sosial yang baik dengan karyawan dan keluarga.

Negosiasi dengan kedua pihak tersebut berlangsung dalam konteks negosiasi formal dan negosiasi informal. Negosiasi formal merupakan negosiasi yang terjadi dalam situasi formal, dengan ciri-ciri adanya perjanjian atau hitam di atas putih yang sah secara hukum. Oleh karena itu, pelanggaran terhadap perjanjian yang telah disepakati dapat diperkarakan ke ranah hukum. Negosiasi informal terjadi dalam kehidupan sehari-hari dan dapat terjadi kapan saja, dimana saja, dan dengan siapa saja.

Negosiasi formal ditandai dengan persiapan yang dilakukan oleh informan, mulai dari pra negosiasi, pelaksanaan negosiasi dan pasca negosiasi. Selain itu, negosiator akan mempersiapkan "dirinya" melalui persiapan fisik (penampilan), membuat proposal dan menyiapkan contoh produk. Adapun negosiasi informal merupakan negosiasi yang dilakukan tanpa persiapan, berlangsung dalam berbagai aspek kehidupan sosial terutama dengan
Adapun negosiasi informal merupakan negosiasi yang dilakukan tanpa persiapan, berlangsung dalam berbagai aspek kehidupan sosial terutama dengan pihak keluarga yaitu dengan suami dan anak (yang sudah menikah) dan dengan orangtua (yang belum menikah). Dalam praktiknya, kedua negosiasi tersebut dilakukan terhadap pihak internal maupun eksternal. Secara umum, negosiasi formal dilakukan dengan pihak eksternal. Adapun negosiasi informal yang dilakukan terhadap pihak eksternal biasanya dilakukan dalam bentuk "lobi" ke berbagai pihak untuk mendapatkan klien. Dalam situasi ini, substansi bahasannya formal tetapi teknik komunikasinya cair diselingi dengan hiburan ringan, makan ringan dan canda secukupnya.

Negosiasi formal dengan pihak internal berlangsung dalam situasi kerja dilakukan terhadap karyawan menyangkut hubungan "industrial" tentang hak dan kewajiban informan dan karyawan. Dalam kondisi tertentu, informan lebih banyak melakukan negosiasi secara informal karena informan memperlakukan karyawan sebagai bagian dari keluarganya juga. Hal ini terjadi, selain karena karyawan tersebut merupakan saudara dari kampung ataupun tetangga sekitar yang memang sudah lama berhubungan baik dengan informan. Adapun negosiasi dengan pihak keluarga, misalnya suami berlangsung secara informal walaupun yang dibahas hal-hal yang berkaitan dengan keberlangsungan bisnis yang dijalankan oleh informan. 
Selanjutnya, untuk mendapatkan hasil negosiasi yang menguntungkan, informan menjalankan berbagai strategi yang diharapkan akan menghasilkan kesepakatan bagi kedua pihak. Strategi tersebut sangat memperhitungkan kondisi informan sebagai seorang perempuan, antara lain strategi penetapan waktu, strategi penentuan lokasi, startegi penggunaan media, dan strategi tawar-menawar. Strategi penetapan waktu, lokasi dan penggunaan media disiapkan pada pra negosiasi, sedangkan pada pelaksaan negosiasi diterapkan strategi tawar-menawar distributif dan strategi tawar-menawar integratif. Pada kenyataannya, strategi tawarmenawar distributif berlangsung dalam berbagai kehidupan, karena memungkinkan hasil dalam kondisi zero sum, ada pihak yang mau melepas tawarannya atau sebaliknya mempertahankan tawarannya agar terjadi kesepakatan. Hubungan jangka panjang tidak menjadi pertimbangan dalam tawar-menawar distributif.

Mangkusubroto (2010: 27-30) menyatakan bahwa dalam tawar-menawar distributif, para informan hendaknya mempertimbangkan beberapa hal yang berkaitan dengan :

(1) reservation point yaitu kondisi terburuk yang dapat diterima sebagai hasil negosiasi (kesepakatan) dan aspiration point atau target point yaitu konsisi (hasil) yang paling diharapkan,
(2) zona tawar-menawar yaitu kondisi para negosiator hanya akan melakukan tawar-menawar dalam area yang tidak memberikan hasil lebih buruk dibandingkan reservation point-nya, (3) Best Alternative to a Negotiated Agreement (BATNA) yaitu alternatif terbaik yang kita miliki sebelum bernegosiasi dengan lawan negosiasi saat ini,

(4) negotiator surplus yaitu ukuran yang menunjukkan sebaik apa hasil yang diproleh seorang negosiator relatif terhadap lawan negosiasinya.

Hal yang berbeda terjadi pada tawarmenawar integratif yang mengutamakan hasil negosiasi yang memuaskan kedua belah pihak. Kesepakatan terjadi bukan karena saling membagi sama tawaran, tetapi karena masingmasing pihak rela "melepas" apa yang menjadi tawarannya untuk mendapatkan konsesi dari pihak lain, dan demikian sebaliknya. Posisi yang terjadi adalah adanya keseimbangan yang menguntungkan kedua belah pihak. Dengan demikian, seorang negosiator yang menerapkan strategi integratif fokus pada kesamaan dan bukan pada perbedaan, berusaha memenuhi kebutuhan dan kepentingan bukan posisi, berkomitmen memenuhi kebutuhan semua pihak yang terlibat, bertukar informasi dan ide, menciptakan pilihan-pilihan untuk keuntungan bersama, dan menggunakan kriteria yang obyektif untuk standar kerja (Lewicki, 2012: 89). 
Berdasarkan penjelasan di atas menunjukkan bahwa proses pengambilan keputusan negosiator tidak hanya kompleks karena berkaitan dengan proses komunikasi, tetapi pada kenyataannya melibatkan berbagai orang yang berbeda cara berfikinya, adanya informasi faktual tentang berbagai isu yang dikemukakan secara implisit atau eksplisit selama negosiasi berlangsung, dan juga dipengaruhi oleh emosi. Hal yang penting menjadi perhatian adalah pelaku negosiasi harus fokus pada interest, bukan pada posisi yang ditawarkan. Artinya, menitikberatkan pada alasan yang melatarbelakangi diajukannya proposal/penawaran.

\section{SIMPULAN}

Bisnis yang dijalankan oleh perempuan wirausaha agribisnis pangan di Bogor termasuk kategori UMKM, hal ini memberikan implikasi pada proses negosiasi yang dilakukan lebih bersifat informal yang dipengaruhi kondisi bisnis yang menjadi konteks negosiasi tersebut. Proses negosiasi mengedepankan aspek emosional yang dibangun melalui kebersamaan dan kekeluargaan.. Hal ini antara lain disebabkan karena berbagai pihak yang menjadi klien negosiasi telah dikenal lama atau sudah berhubungan cukup lama dalam melakukan kerjasama bisnis. Proses negosiasi menjadi formal dan kompleks dan bersifat rasional, ketika negosiasi dilakukan dengan lembaga formal yang telah mapan, misalnya rumah sakit, pewaralaba, hotel, sekolah, atau swalayan.
Formalitas tersebut ditunjukkan dengan adanya kontrak yang disepakati oleh kedua belah pihak.

Strategi negosiasi yang menjadi dilakukan oleh perempuan wirausaha agribisnis pangan di Bogor adalah strategi, waktu, tempat, distributif dan integratif. Strategi waktu dan tempat menjadi perhatian, karena kedua hal tersebut menjadi keterbatasan dalam melakukan negosiasi berkaitan dengan statusnya sebagai ibu rumahtangga yang lebih mendahulukan urusan keluarga dari bisnisnya dan kekhawatiran akan persepsinegatif dari masyarakat terhadap dirinya

\section{REFERENSI}

Browne, J. (1979). "The Used Car Games" dalam The Research Expererience. M. Patricia Golden (Editor). Illinois: F.E Peacock Publishers.

Canet_Giner, M.T., dan Saorin-Iborra, M.C. (2007). The Influence of Gender Role on Negotiation Development and Outcome : A Proposal for Strategic Alliance Negotiations. Equal Opportunities International, Vol. 26 Iss: 3, p. 209-231.

Creswell, J.D. (1998). Qualitative Inquairy and Research Design: Choosing Among Five Tradition. London: Sage Publication Inc. 


\section{PROSES NEGOSIASI PEREMPUAN WIRAUSAHA AGRIBISNIS PANGAN BERDASARKAN PENDEKATAN SISTEM AGRIBISNIS DI KOTA BOGOR}

Creswell, J.,W. (2013). Research Design Pendekatan Kualitatif, Kuantitatif, dan $\mathrm{M} \mathrm{i} \mathrm{x}$ e d. T e $\mathrm{r} \mathrm{j}$ e $\mathrm{m}$ a $\mathrm{h}$ a $\mathrm{n}$. Yogyakarta:Pustaka Pelajar.

Johnson, D.P. (1986). Teori Sosiologi Klasik dan Modern. Jakarta: PT. Gramedia.

Liliweri, A. (1991). Perspektif Teoritis Antar Pribadi. Bandung : PT Citra Aditya Bakti.

Kilgour, D.M, dan Eden, C. (2010). Handbook of Group Decision and Negotiation. New York: Springer.

Kuswarno, E. (2013). Metode Penelitian Komunikasi Fenomenologi, Konsepsi, Pedoman, dan Contoh Penelitiannya. Bandung: Widya Padjadjaran.

Mangkusubroto. K. (2010). Konsep Negosiasi. Bandung: Rekayasa Sains.

Moleong, L. (2000). Metodologi Penelitian Kualitatif. Bandung: Remadja Rosdakarya.

Morissan. (2013). Teori Komunikasi : Individu hingga Massa.Jakarta: Kencana Prenada Media Grup.
Mulyana, D. (2001). Metodologi Penelitian Kualitatif : Paradigma Baru Ilmu Komunikasi dan Ilmu Sosial Lainnya. Cetakan Pertama. Bandung: PT Remaja Karya.

Nandonde, F.,A., dan Liana, P., J. Analysis of Women Small Scale Entrepreneur Practices during Business Negotiations in Tanzania Agribusiness. Journal of Languages, Technology and Entrepreneur, Vol 4 (2), 2013.

Nieuwmeijer, L. (1998). Negotiation: Methodology and Training. Pretoria: HSRC Publishers.

West, R., dan Turner L.H. (2008). Pengantar Teori Komunikasi: Analisis dan Aplikasi (Terjemahan). Jakarta: Salemba Humanika.

Yu, E. (2011). Are Women Entrepreneurs More Likely to Share Power than Men Entrepreneurs in Decision-Making. International Journal of Business Management, Vol. 6, No. 4. April, p. 111-119. 